\title{
Export Market Effectiveness: The Role of Export Commitment, Innovativeness and Marketing Capabilities
}

\author{
Completed Research Paper
}

\author{
Margarida Vicente \\ Instituto Politécnico de Viseu \\ margarida@estv.ipv.pt \\ Maria José Antunes \\ Instituto Politécnico de Viseu \\ maria.jose.1.antunes@gmail.com
}

\author{
Cláudia Seabra \\ Instituto Politécnico de Viseu \\ cseabra@estv.ipv.pt
}

\begin{abstract}
Drawing on the resource-based view, this study investigates the way that export commitment and innovativeness contribute to marketing capabilities development, and the effect of all these factors on export market effectiveness. We use a survey data of 202 exporting manufacturing firms based in Portugal to test the relationships between the constructs analyzed in this study. The findings demonstrate that a high export commitment tends to cultivate a higher degree of innovativeness, which in turn allows firms to develop superior marketing capabilities (i.e., pricing, new product development, marketing communication and distribution capabilities). Export commitment and new product development capability have a direct impact on export market effectiveness.
\end{abstract}

Keywords: Export commitment; Innovativeness; Marketing capabilities; Export market effectiveness. 


\section{Introduction}

Understanding the drivers of export market effectiveness is fundamental to explain firms' international competitiveness (Morgan, Katsikeas, \& Vorhies, 2012). According to the resource-based view (RBV), firms' internal resources and capabilities are critical to achieve a sustainable competitive advantage and thus a greater market performance (Barney, 1991; Newbert, 2007; Wernerfelt, 1984).

In this context, distinctive marketing capabilities have proven to be key drivers for financial and market export performance (e.g., Morgan et al., 2012; Rust, Ambler, Carpenter, Kumar, \& Srivastava, 2004). They are a strategic response to competitive environment (O'Cass \& Weerawardena, 2010), enabling firms to anticipate and respond to market needs, and thus outperform the competition (Day, 1992, 1994). This link between marketing capabilities and export market performance is important, however, it is also important to explain the mechanisms leading to marketing capabilities creation and development (Merrilees, RundleThiele, \& Lye, 2011). So, how exporting firms may develop their marketing capabilities?

There has been a substantial debate in the strategic marketing literature about the link between innovativeness and marketing capabilities (e.g., Kerin, 1992; Weerawardena, 2003). Firms pursuing an innovation-based strategy create specific capabilities that enable them to respond in a more effective way to technological and customers' changes (Rizzoni, 1991). Innovativeness influences marketing capabilities development, especially for firms who compete in dynamic markets (O'Cass \& Weerawardena, 2010). In addition, past research reflects a growing interest in the influence of the firms' level of resources in the development of innovativeness (e.g., Amabile, Conti, Coon, Lazenby, \& Herron, 1996; Hurley \& Hult, 1998). Accordingly, resources commitment to exporting generate a culture of innovativeness within the firm (Jong \& Hartog, 2007), which in turn leads to the development of internal capabilities (McGrath \& Ming-Hone, 1996), such as marketing capabilities.

These insights guide the theoretical foundation for the current study, which links export commitment, innovativeness and marketing capabilities to performance in export markets. We demonstrate how specific marketing capabilities (i.e., pricing, new product development, marketing communication and distribution capabilities) may be improve through the firm's export commitment and its degree of innovativeness. In this research, we adopt the RBV to examine export commitment as a resource, specifically the level of resources committed to exporting, that can generate a superior performance in export markets (Barney, 1991). We empirically test the direct impact of export commitment, innovativeness and marketing capabilities on export market effectiveness. In addition, considering that different marketing capabilities may have different strengths based on their context (Zahra, Sapienza, \& Davidsson, 2006), we examine the relative contribution of each marketing capability towards export market effectiveness.

\section{Literature Review and Research Hypotheses}

In the exporting field, the RBV is one of the most widely accepted theories to explain why firms perform differently (e.g., Kaleka, 2012; Lages, Silva, \& Styles, 2009). According to the RBV (e.g., Barney, 1991; Newbert, 2007; Wernerfelt, 1984), firms with valuable, rare, inimitable and non-substitutable resources and capabilities can generate sustainable competitive advantage by implementing strategies that improve their efficiency and effectiveness (Barney, 1991). Export commitment, innovativeness and marketing capabilities are complex bundles of resources, skills and collective learning, based on knowledge that is tacit and difficult to copy for competitors (Krasnikov \& Jayachandran, 2008). These resources 
and competences cannot be simply traded or imitated because they are deeply embedded in organizational routines and processes (Day, 1994; Prahalad \& Hamel, 1990). Consequently, they are idiosyncratic firms attributes, relevant to achieve a superior performance in export markets (cf., Barney, 1991).

Innovativeness is a characteristic of organizational culture that encompasses the ability to generate and implement new and creative ideas within a firm (Amabile et al., 1996; Calantone, Cavusgil, \& Zhao, 2002; Jong \& Hartog, 2007; Zhao, Tong, Wong, \& Zhu, 2005).

Export commitment is the degree to which a firm allocates managerial and organizational resources to the export venture (Lages, Jap, \& Griffith, 2008; Lages \& Montgomery, 2004). The consequently ongoing effort to improve products and services provided in export market, creates a new mindset or attitudes that stimulate the implementation of new and useful ideas as a part of an innovativeness culture (Hurley \& Hult, 1998). Through increasing levels of managerial, financial and human resources committed to exporting, and the assignment of dedicated people, a firm demonstrates a greater receptivity to new ideas and concepts, which makes it more willing to engage in innovativeness (Jong \& Hartog, 2007). According to this, we propose the following hypothesis:

Hypothesis 1 . The firm's export commitment positively influences innovativeness.

Marketing capabilities are defined as the firm's ability to understand and forecast customer's needs and to effectively link its offerings to these needs (Katsikeas, 1994; Sousa \& Lages, 2011).

A firm with a higher degree of innovativeness demonstrates a greater hability to generate creative marketing skills and suitable products and services to reach the target market effectively (Nath, Nachiappan, \& Ramanathan, 2010; O'Cass \& Weerawardena, 2010). So, innovativeness contributes for the development of distinctive marketing capabilities, enabling a firm to improve price, product, communication and distribution capabilities, and adapt them to the particularities of each export market (Navarro, Losada, Ruzo, \& Díez, 2010). In line with the above, we propose the following hypotheses:

Hypotheses 2. The firm's innovativeness positively influences:

H2a. pricing capability, H2b. new product development capability, H2c. marketing communication capability, and $\mathrm{H} 2 \mathrm{~d}$. distribution capability.

Commitment is related to the allocation of greater resources to the venture, enabling a firm to achieve its exporting goals (Lages \& Montgomery, 2004; O'Cass \& Julian, 2003). The more committed the firm, the greater is its engagement in planning and the allocation of managerial, financial and human resources to the export venture, which in turn results in a better export venture performance (e.g., Lado, Martínez-Ros, \& Valenzuela, 2004; Navarro, Losada, et al., 2010). Thus, we propose the following hypothesis:

Hypothesis 3. The firm's export commitment positively influences export market effectiveness.

Innovativeness conditions the entire organization with an innovative culture that allows the firm to respond to the competitiveness and adapt to changes that occur in the business environment (Akman \& Yilmaz, 2008; Hult, Hurley, \& Knight, 2004; Zhao et al., 2005). Thereby, innovativeness is critical to achieve superior market effectiveness (e.g., Calantone et al., 2002; Hult et al., 2004; Rhee, Park, \& Lee, 2010). According to this, we propose the following hypothesis:

Hypothesis 4. The firm's innovativeness positively influences export market effectiveness.

Through their marketing capabilities, firms create and maintain strong bonds with customers and channel members (Nath et al., 2010; Song, Benedetto, \& Nason, 2007), increasing knowledge about foreign customers' needs, competitive behaviors and market trends (Day, 1994). This enable them to satisfy customers additionally, even more than their competitors (Weerawardena \& O'Cass, 2004), and thus to obtain a greater performance in the 
export market (e.g., Murray, Gao, \& Kotabe, 2011; Vorhies \& Morgan, 2005). In line with the above, we propose the following hypotheses:

Hypotheses 5. The export market effectiveness is positively influenced by:

H5a. pricing capability, H5b. new product development capability, H5c. marketing communication capability, and $\mathrm{H} 5 \mathrm{~d}$. distribution capability.

\section{Methodology}

Data for this study was collected in 2012, using a sample of Portuguese exporting manufacturers. The study focuses exclusively on exporter manufacturing firms (e.g., Morgan, Kaleka, \& Katsikeas, 2004), with more than 20 employees (e.g., Lisboa, Skarmeas, \& Lages, 2011), and who had been active in exporting for at least five years. We selected a random sample of 3000 firms from the Trade \& Investment Agency (AICEP Portugal Global) government database. An online questionnaire was the basis of the data used to test the model. We obtained 202 valid questionnaires.

\section{Results}

We assessed the measurement model proprieties and analyzed the structural equation model using partial least squares (PLS) with the statistics package SmartPLS 2.0 (Ringle, Wende, \& Will, 2005). We opted for the PLS approach because it is the most suitable when the sample size has between 100 and 250 observations (Reinartz, Haenlein, \& Henseler, 2009). The evaluation of PLS model follows a two-step process (Hair, Hult, \& Ringle, 2014). First, we evaluate the measurement model and then we evaluate the structural model.

Table 1 presents the final constructs, items, and scale reliabilities. 
Table 1: Construct Measurement

Export commitment $(\alpha=0.88, \rho v c(n)=0.81, \rho=0.93)$ (adapted from Navarro, Acedo et al., 2010)

Scale: 1-very low; 7-very high

1. The level of time and effort our firm's management commits to export activity is:

2. The level of financial resources committed to the export activity is:

3. The level of human resources committed to the export activity is:

Innovativeness $(\alpha=0.87, \rho v c(n)=0.79, \rho=0.92)$ (adapted from Calantone et al., 2002)

Scale: 1 -strongly disagree; 5 -strongly agree

1. Our company frequently tries out new ideas

2. Our company seeks out new ways to do things

3. Our company is creative in its methods of operation

Pricing capability $(\alpha=0.75, \rho v c(n)=0.65, \rho=0.85)$ (adapted from Zou et al., 2003)

Scale: 1 -strongly disagree; 5 -strongly agree (relative to major export market competitors)

1. We respond quickly to competitors' pricing tactics

2. We use pricing skills to respond quickly to any customer change

3 . We communicate pricing structures and levels quickly to customers

New product development capability $(\alpha=0.84, \rho v c(n)=0.67, \rho=0.89)$ (adapted from Zou et al., 2003)

Scale: 1-strongly disagree; 5 -strongly agree (relative to major export market competitors)

1. We develop new products for export to exploit $R \& D$ investment

2. We speedily develop and launch new products for export

3. We manage overall new product development systems for export market well

4. We successfully launch new products for exports

Marketing communication capability $(\alpha=0.97, \rho v c(n)=0.94, \rho=0.98)$ (adapted from Zou et al., 2003)

Scale: 1-strongly disagree; 5 -strongly agree (relative to major export market competitors)

1 . We skillfully use marketing communications

2. We use marketing communication skills and processes well

3. We effectively manage marketing communication programs

Distribution capability $(\alpha=0.95, \rho v c(n)=0.82, \rho=0.96)$ (adapted from Zou et al., 2003)

Scale: 1-strongly disagree; 5 -strongly agree (relative to major export market competitors)

1. We attract and retain the best distributors

2. We satisfy the needs of distributors

3. We add value to distributors' businesses

4. We are close in working with distributors/retailers

5. We provide high level of support to distributors

Export market effectiveness $(\alpha=0.90, \rho v c(n)=0.77, \rho=0.93)$ (adapted from Morgan et al., 2006)

Scale: 1-much worse than competitors; 5-much better than competitors

1. Export venture's market share growth

2. Growth in export venture sales revenue

3. Acquiring new export venture customers

$\alpha=$ internal reliability; $\rho \mathrm{vc}(\mathrm{n})=$ variance extracted; $\rho=$ composite reliability.

$* \mathrm{p}<0.01$ (2-tailed)

Indicator reliability was assessed examining the standardized loading of the individual item or indicator in the respective constructs. All the standardized loadings are greater than 0.708 , which is the minimum value to accept an indicator as part of a construct (Hair et al., 2014).

Internal consistency reliability was assessed using traditional Cronbach's alpha. All constructs meet the generally agreed minimum limit of 0.7 (Robinson, Shaver, \& 
Wrightsman, 1991). As an additional indicator of internal consistency, composite reliability (Bagozzi, 1980) was also calculated for each construct. All constructs meet the suggested minimum acceptable level for composite reliability of 0.7 (Nunnally \& Bernstein, 1994).

Convergent validity was assessed by calculating the average variance extracted (AVE) (Fornell \& Larcker, 1981). All values are greater than 0.5, indicating convergent validity (Hair et al., 2014).

Discriminant validity was assessed by using Fornell-Larcker criterion (Fornell \& Larcker, 1981). Table 2 provides an overview of the means, standard deviations, and correlation matrix among the constructs. Adequate discriminant validity is evident since the square root of AVE between any two constructs (diagonal) is greater than the correlation between those constructs (off-diagonal).

Table 2: Correlations between constructs ${ }^{\mathrm{a}}$

\begin{tabular}{|c|c|c|c|c|c|c|c|}
\hline Construct & 1 & 2 & 3 & 4 & 5 & 6 & 7 \\
\hline 1. Export commitment & 0.90 & & & & & & \\
\hline 2. Innovativeness & 0.33 & 0.89 & & & & & \\
\hline 3. Pricing capability & 0.11 & 0.21 & 0.81 & & & & \\
\hline 4. New product development capability & 0.24 & 0.63 & 0.31 & 0.82 & & & \\
\hline 5. Marketing communication capability & 0.17 & 0.39 & 0.40 & 0.51 & 0.97 & & \\
\hline 6. Distribution capability & 0.10 & 0.39 & 0.28 & 0.47 & 0.46 & 0.91 & \\
\hline 7. Export market effectiveness & 0.21 & 0.23 & 0.21 & 0.39 & 0.23 & 0.23 & $\mathbf{0 . 8 8}$ \\
\hline
\end{tabular}

a The diagonal (in bold) shows the square roots of the average variance extracted.

After the evaluation of measurement model, we proceed with the evaluation of the structural model in order to determine how well empirical data support the proposed model.

In order to assess the possible existence of collinearity, we compute the tolerance variance inflation factor (VIF) for each set of predictor constructs. All VIF values are below the cut-off value of 5, indicating that collinearity is not an issue in this study (Hair et al., 2014).

Following Hair, Hult and Ringle (2014) recommendations, to evaluate the significance of parameter estimates, we used 5,000 bootstrap samples. We used the individual sign change option to obtained standard errors and t-values. Figure 1 presents results of the PLS estimation, including the standardized path coefficients $(\beta)$, and t-values. 


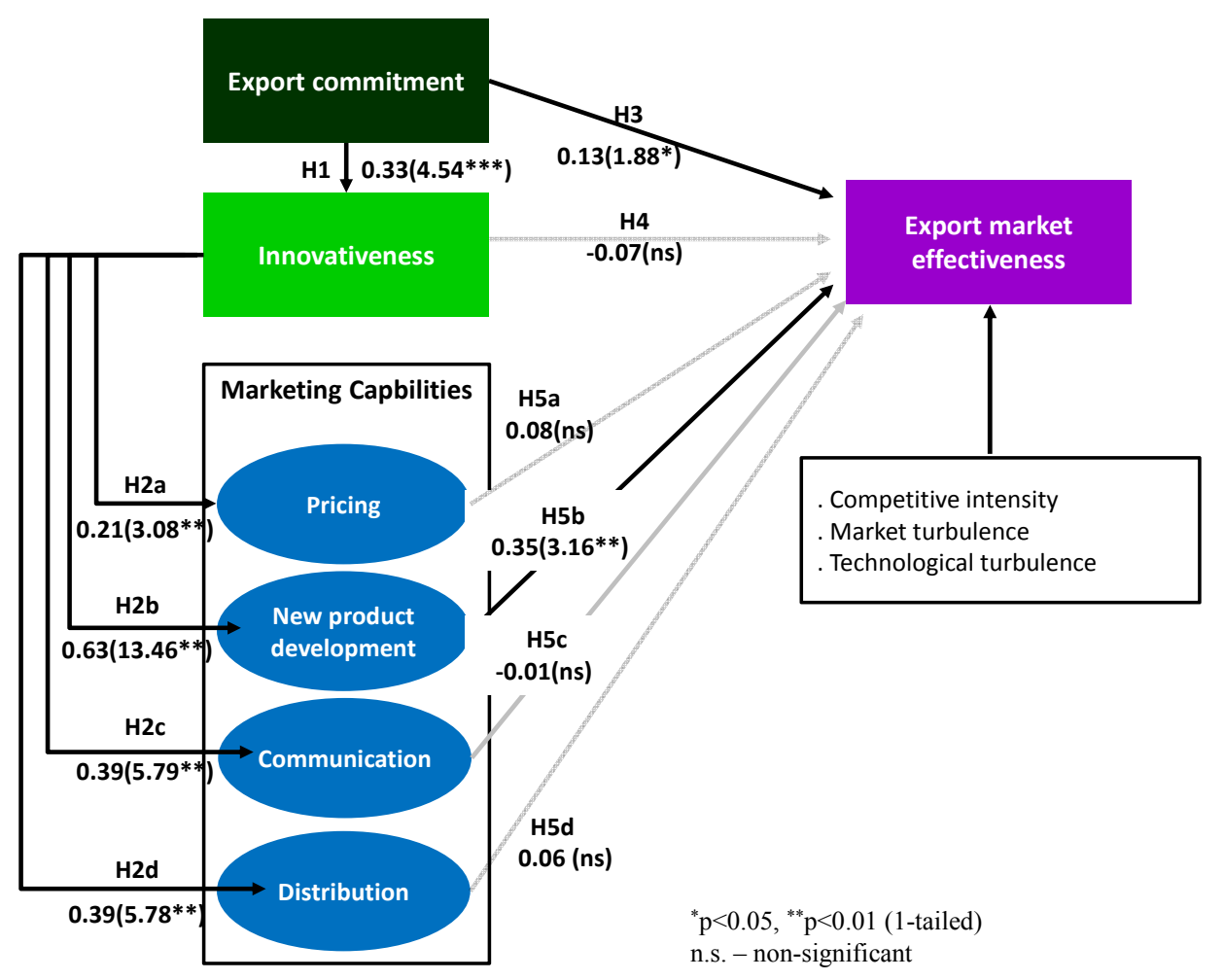

Figure 1: Testing results

Consistent with $\mathrm{H} 1$, export commitment positively influences innovativeness $(\beta=0.33$, tvalue=4.54). In line with $\mathrm{H} 2 \mathrm{a}, \mathrm{H} 2 \mathrm{~b}, \mathrm{H} 2 \mathrm{c}$ and $\mathrm{H} 2 \mathrm{~d}$, innovativeness has a significant positive impact on pricing capability $(\beta=0.21$, $t$-value $=3.08)$, new product development capability $(\beta=0.63$, t-value $=13.46)$, marketing communication capability $(\beta=0.39, \mathrm{t}$-value $=5.79)$, and distribution capability $(\beta=0.39$, $\mathrm{t}$-value $=5.78)$. In support of $\mathrm{H} 3$, export commitment has a significant positive impact on export market effectiveness $(\beta=0.13$, t-value $=1.88)$. Contrary to expectations, no significant relation is found between innovativeness and export market effectiveness $(\beta=-0.07$, n.s.), so H4 is rejected. Likewise, no significant association is found between pricing capability and export market effectiveness $(\beta=0.08$, n.s.), thus H5a is rejected. Consistent with $\mathrm{H} 5 \mathrm{~b}$, new product development capability has a significant positive impact on export market effectiveness $(\beta=0.35$, $t$-value $=3.16)$. Finally, no significant relation is found between marketing communication and export market effectiveness $(\beta=-0.01$, n.s.), and between distribution and export market effectiveness $(\beta=0.06$, n.s.), so H5c and H5d are rejected.

The analytical results also allow us to draw conclusions about the relative importance of the predictor variables used in the model. For the four endogenous variables that constitute marketing capabilities, the findings establish that innovativeness has a stronger impact on new product development capability $(\beta=0.63)$, than on marketing communication capability ( $\beta=0.39)$, and on distribution capability $(\beta=0.39)$, that is equal, and greater than the impact of innovativeness on pricing capability $(\beta=0.21)$. Thus, innovativeness contributes more strongly to the new product development capability.

Regarding the endogenous variable export market effectiveness, only two of the five predictor variables are significant. New product development capability has a stronger impact on export market effectiveness $(\beta=0.35)$, than export commitment $(\beta=0.13)$. Therefore, new product development capability contributes more strongly to export market effectiveness. In total, these variables explain $18 \%$ of the variance in export market effectiveness $\left(\mathrm{R}^{2}=.18\right)$, with a predictive ability $\left(\mathrm{Q}^{2}\right)$ of 0.14 .

We also included three environmental variables, derived from Kaleka (2012), as control 
variables (i.e., competitive intensity, market turbulence and technological turbulence). It should be noted that none of them has significant impacts on export market effectiveness.

In addition, the indirect effect of innovativeness on export market effectiveness is positively statistically significant $(\beta=0.26)$. Despite the non-significant direct impact of innovativeness on export market effectiveness, the total effects remain significant $(\beta=0.19$, $\mathrm{p}<0.01)$.

\section{Discussion and Implications}

The study offers two important contributions to the international marketing literature. First, it gives an extended and integrated vision of the role of export commitment and innovativeness in marketing capabilities development. Second, it increases the comprehension of the RBV in export markets, by empirically examining the impact of export commitment, innovativeness and marketing capabilities on export market effectiveness.

As predicted, export commitment directly leads to a higher degree of innovativeness and indirectly to the development of superior marketing capabilities. The allocation of important resources to export venture encourages the development of innovative behaviors within firms, like frequently try out new ideas, seek new ways to do things, and being creative in operation methods. This, in turn, allows companies to develop innovative price, product, communication and distribution capabilities in order to better forecast customers' needs and competitors' actions (cf., McGrath \& Ming-Hone, 1996).

This way, we add understanding to marketing capabilities development, by demonstrating that such development indirectly depends on firms' resources committed to export activity and directly on their level of innovativeness. In consequence, we argue that managers need to invest ample time and effort, and also allocate the appropriate financial and human resources to export activity, to achieve a greater innovativeness, and thus to develop superior marketing capabilities (cf., Lado et al., 2004).

We adopted the RBV to examine export commitment as a resource. We focused on export commitment as the level of resources committed to exporting, and we tested its impact on export market effectiveness. The results support the argument that export commitment enables firms to obtain superior export market effectiveness, whether directly or indirectly through innovativeness and marketing capabilities. This is consistent with previous research, that point out that resources committed to export venture act as a determinant of managers' satisfaction with the achievement of their objectives in the export market (e.g., Cavusgil \& Zou, 1994; Lages et al., 2008; Navarro, Losada, et al., 2010). Through the application of the $\mathrm{RBV}$, we provide theoretical contributions for the importance of export commitment as a critical resource for firms to achieve superior performance in export markets. Furthermore, we demonstrate the importance of innovativeness in transforming these resources committed to exporting into valuable outcomes for the export markets.

The analysis of the influence of marketing capabilities on export market effectiveness demonstrates that new product development capability has a significant and positive impact on export market effectiveness. The findings show that firms with new product development capability can successfully develop and launch new products for export markets, which allow them to meet the customers' needs in a more effective way (e.g., Eng \& Spickett-Jones, 2009).

Surprisingly, pricing, marketing communication and distribution capabilities have no effects on export market effectiveness. This can happen due to the not always significant influence of many marketing capabilities on export market effectiveness, as evidenced by the literature (e.g., Eng \& Spickett-Jones, 2009; Zou, Fang, \& Zhao, 2003). Also surprisingly, we 
did not confirm the existence of a significant relation between innovativeness and export market effectiveness. This is probably because firms' innovativeness must be associated with the development of new products for export markets, as well as the ability to communicate and manage marketing programs to these markets. Innovativeness by itself does not translate in market share and sales revenue growth, in the acquisition of new customers, or in increased sales to existing customers. Instead, the effectiveness of innovativeness depends on how it operates in new product development capability.

Overall, our results support the RBV (e.g., Barney, 1991; Newbert, 2007) linking resources and capabilities, specifically export commitment and new product development capability, directly to export market effectiveness. The findings demonstrate that the magnitude of the effect of new product development capability on export market effectiveness is almost three times higher comparatively to the size of the impact of export commitment on export market effectiveness. This suggests that managers need especially to improve new product development capability in order to enhance performance in export markets. However, when managers develop new products to enhance export market performance effectively, they should also develop export commitment and innovativeness to excel in the international market competition.

\section{Limitations and Future Research}

This study presents some suggestions for future research concerning the theoretical and methodological limitations.

Longitudinal data may improve this type of investigation, analyzing how changes in firms' export commitment, innovativeness, marketing capabilities, and business environment can affect export market effectiveness. The cross-sectional data used in this study may not be adequate in identifying fundamental relationships among the constructs.

Future studies based on samples from various countries are encouraged, since only firms based in Portugal were surveyed.

Other factors may be considered as antecedents of marketing capabilities, innovativeness, export commitment or export market effectiveness itself, such as market orientation (e.g., Murray et al., 2011; Navarro, Acedo, Robson, Ruzo, \& Losada, 2010; Trainor, Rapp, Beitelspacher, \& Schillewaert, 2011), learning orientation (e.g., O'Cass \& Weerawardena, 2010), and entrepreneurial intensity (e.g., Weerawardena \& O'Cass, 2004).

Other types of marketing capabilities and their effects on export market effectiveness may be considered for future research, like channel management and post-sale service (e.g., Morgan et al., 2012), customer relationship management (e.g., Morgan, Slotegraaf, \& Vorhies, 2009), and brand management (e.g., Trainor et al., 2011).

Finally, we used three control variables (competitive intensity, market turbulence and technological turbulence) which can be treated as potential moderating factors in future studies, concerning the role of environmental context in the deployment of firms' resources and capabilities to achieve superior performance in export markets.

\section{Acknowledgments}

The Portuguese Foundation for Science and Technology (FCT) through the project PEstOE/CED/UI4016/2014, and the Center for Studies in Education, Technologies and Health (CI\&DETS).

\section{References}


Akman, G., \& Yilmaz, C. (2008). Innovative capability, innovation strategy and market orientation: an empirical analysis in Turkish software industry. International Journal of Innovation Management, 12(1), 69-111.

Amabile, T. M., Conti, R., Coon, H., Lazenby, J., \& Herron, M. (1996). Assessing the work environment for creativity. The Academy of Management Journal, 39(5), 1154-1184.

Bagozzi, R. P. (1980). Causal Models in Marketing. New York: John Wiley \& Sons Inc.

Barney, J. B. (1991). Firm resources and sustained competitive advantage. Journal of Management, 17(1), 99-120.

Calantone, R. J., Cavusgil, S. T., \& Zhao, Y. (2002). Learning orientation, firm innovation capability, and firm performance. Industrial Marketing Management, 31(6), 515-524.

Cavusgil, S. T., \& Zou, S. (1994). Marketing strategy-performance relationship: an investigation of the empirical link in export market ventures. Journal of Marketing, 58(1), 1-21.

Day, G. S. (1992). Marketing's contribution to the strategy dialogue. Journal of the Academy of Marketing Science, 20(4), 323-329.

Day, G. S. (1994). The capabilities of market-driven organizations. [Article]. Journal of Marketing, 58(4), 37-52.

Dutta, S., Narasimhan, O., \& Rajiv, S. (1999). Success in high-technology markets: is marketing capability critical? Marketing Science, 18(4), 547-568.

Eng, T.-Y., \& Spickett-Jones, J. G. (2009). An investigation of marketing capabilities and upgrading performance of manufacturers in mainland China and Hong Kong. Journal of World Business, 44(4), 463-475.

Fornell, C., \& Larcker, D. F. (1981). Evaluating structural equation models with unobservable variables and measurement error. Journal of Marketing Research, 18(1), 39-50.

Hair, J. F., Hult, G. T. M., \& Ringle, C. (2014). A Primer on Partial Least Squares Structural Equation Modeling (PLS-SEM): Thousand Oaks: Sage.

Hult, G. T. M., Hurley, R. F., \& Knight, G. A. (2004). Innovativeness: its antecedents and impact on business performance. Industrial Marketing Management, 33(5), 429-438.

Hurley, R. F., \& Hult, G. T. M. (1998). Innovation, market orientation, and organizational learning: an integration and empirical examination. Journal of Marketing, 62(3), 4254.

Jong, J. P. J., \& Hartog, D. N. D. (2007). How leaders influence employees' innovative behaviour. European Journal of Innovation Management, 10(1), 41-64.

Kaleka, A. (2012). Studying resource and capability effects on export venture performance. Journal of World Business, 47(1), 93-105.

Katsikeas, C. S. (1994). Export competitive advantage: the relevance of firm characteristics. International Marketing Review, 11(5), 33-53.

Kerin, R. (1992). Marketing's contribution to the strategy dialogue revisited. Journal of the Academy of Marketing Science, 20(4), 331-334.

Krasnikov, A., \& Jayachandran, S. (2008). The relative impact of marketing, research-anddevelopment, and operations capabilities on firm performance. Journal of Marketing, 72(4), 1-11.

Lado, N., Martínez-Ros, E., \& Valenzuela, A. (2004). Identifying successful marketing strategies by export regional destination. [Article]. International Marketing Review, 21(6), 573-597.

Lages, L. F., Jap, S. D., \& Griffith, D. A. (2008). The role of past performance in export ventures: a short-term reactive approach. Journal of International Business Studies, 39(2), 304-325.

Lages, L. F., \& Montgomery, D. B. (2004). Export performance as an antecedent of export 
commitment and marketing strategy adaptation: evidence from small and mediumsized exporters. European Journal of Marketing, 38(9/10), 1186-1214.

Lages, L. F., Silva, G., \& Styles, C. (2009). Relationship capabilities, quality, and innovation as determinants of export performance. Journal of International Marketing, 17(4), 4770.

Lisboa, A., Skarmeas, D., \& Lages, C. (2011). Entrepreneurial orientation, exploitative and explorative capabilities, and performance outcomes in export markets: a resourcebased approach. Industrial Marketing Management, 40(8), 1274-1284.

McGrath, R. G., \& Ming-Hone, T. (1996). Innovation, competitive advantage and rent: a model and test. [Article]. Management Science, 42(3), 389-403.

Merrilees, B., Rundle-Thiele, S., \& Lye, A. (2011). Marketing capabilities: antecedents and implications for B2B SME performance. Industrial Marketing Management, 40(3), 368-375.

Morgan, N. A., Kaleka, A., \& Katsikeas, C. S. (2004). Antecedents of export venture performance: a theoretical model and empirical assessment. Journal of Marketing, 68(1), 90-108.

Morgan, N. A., Katsikeas, C. S., \& Vorhies, D. W. (2012). Export marketing strategy implementation, export marketing capabilities, and export venture performance. [Article]. Journal of the Academy of Marketing Science, 40(2), 271-289.

Morgan, N. A., Slotegraaf, R. J., \& Vorhies, D. W. (2009). Linking marketing capabilities with profit growth. International Journal of Research in Marketing, 26(4), 284-293.

Murray, J., Gao, G., \& Kotabe, M. (2011). Market orientation and performance of export ventures: the process through marketing capabilities and competitive advantages. Journal of the Academy of Marketing Science, 39(2), 252-269.

Nasution, H. N., Mavondo, F. T., Matanda, M. J., \& Ndubisi, N. O. (2011). Entrepreneurship: its relationship with market orientation and learning orientation and as antecedents to innovation and customer value. Industrial Marketing Management, 40(3), 336-345.

Nath, P., Nachiappan, S., \& Ramanathan, R. (2010). The impact of marketing capability, operations capability and diversification strategy on performance: a resource-based view. Industrial Marketing Management, 39(2), 317-329.

Navarro, A., Acedo, F. J., Robson, M. J., Ruzo, E., \& Losada, F. (2010). Antecedents and consequences of firms' export commitment: an empirical study. [Article]. Journal of International Marketing, 18(3), 41-61.

Navarro, A., Losada, F., Ruzo, E., \& Díez, J. A. (2010). Implications of perceived competitive advantages, adaptation of marketing tactics and export commitment on export performance. Journal of World Business, 45(1), 49-58.

Newbert, S. L. (2007). Empirical research on the resource-based view of the firm: an assessment and suggestions for future research. Strategic Management Journal, 28(2), 121-146.

Nunnally, J. C., \& Bernstein, I. H. (1994). Psychometric Theory. New York: McGraw-Hill.

O'Cass, A., \& Weerawardena, J. (2010). The effects of perceived industry competitive intensity and marketing-related capabilities: drivers of superior brand performance. Industrial Marketing Management, 39(4), 571-581.

O’Cass, A., \& Julian, C. C. (2003). Examining firm and environmental influences on export marketing mix strategy and export performance of Australian exporters. European Journal of Marketing, 37(3/4), 366-384.

Prahalad, C. K., \& Hamel, G. (1990). The core competence of the corporation. Harvad Business Review, 68(3), 79-91.

Reinartz, W., Haenlein, M., \& Henseler, J. (2009). An Empirical Comparison of the Efficacy of Covariance-Based and Variance-Based Sem. International Journal of Research in 
Marketing, 26(4), 332-344.

Rhee, J., Park, T., \& Lee, D. H. (2010). Drivers of innovativeness and performance for innovative SMEs in South Korea: Mediation of learning orientation. Technovation, 30(1), 65-75.

Ringle, C., Wende, S., \& Will, A. (2005). SmartPLS Version 2.0 (M3) Beta. Retrieved from

Robinson, J. P., Shaver, P. R., \& Wrightsman, L. S. (1991). Measures of Personality and Social Psychological Attitudes. San Diego: Academic Press.

Rust, R. T., Ambler, T., Carpenter, G. S., Kumar, V., \& Srivastava, R. K. (2004). Measuring marketing productivity: current knowledge and future directions. [Article]. Journal of Marketing, 68(4), 76-89.

Song, M., Benedetto, C. A., \& Nason, R. (2007). Capabilities and financial performance: the moderating effect of strategic type. Journal of the Academy of Marketing Science, 35(1), 18-34.

Sousa, C. M. P., \& Lages, L. F. (2011). The PD scale: a measure of psychic distance and its impact on international marketing strategy. International Marketing Review, 28(2), 201-222.

Trainor, K. J., Rapp, A., Beitelspacher, L. S., \& Schillewaert, N. (2011). Integrating information technology and marketing: An examination of the drivers and outcomes of e-Marketing capability. Industrial Marketing Management, 40(1), 162-174.

Vorhies, D. W., \& Morgan, N. A. (2005). Benchmarking marketing capabilities for sustainable competitive advantage. Journal of Marketing, 69(1), 80-94.

Weerawardena, J. (2003). The role of marketing capability in innovation-based competitive strategy. Journal of Strategic Marketing, 11(1), 15-35.

Weerawardena, J., \& O'Cass, A. (2004). Exploring the characteristics of the market-driven firms and antecedents to sustained competitive advantage. Industrial Marketing Management, 33(5), 419-428.

Wernerfelt, B. (1984). A resource-based view of the firm. Strategic Management Journal, 5(2), 171-180.

Zahra, S. A., Sapienza, H. J., \& Davidsson, P. (2006). Entrepreneurship and dynamic capabilities: a review, model and research agenda. Journal of Management Studies, 43(4), 917-955.

Zhao, H., Tong, X., Wong, P. K., \& Zhu, J. (2005). Types of technology sourcing and innovative capability: An exploratory study of Singapore manufacturing firms. The Journal of High Technology Management Research, 16(2), 209-224.

Zou, S., Fang, E., \& Zhao, S. (2003). The effect of export marketing capabilities on export performance: an investigation of Chinese exporters. Journal of International Marketing, 11(4), 32-55. 